\title{
"No Apple iPhone? You Must Be Canadian": Mobile Technologies, Participatory Culture, and Rhetorical Transformation
}

\author{
Isabel Pedersen \\ Ryerson University
}

\begin{abstract}
Participation with new mobile devices drives new social practices. This article engages in a close analysis of a so-called participatory culture surrounding iPods and iPhones. It offers close rhetorical readings of object phenomena including advertisements, Canadian news stories, and consumer reactions in electronic media. More specifically, this article reveals a rhetorical transformation between the iPod Silhouettes advertising campaign and the iPhone release campaign, causing a shift in subjectivity; iPod subjects are afforded a degree of freedom and play, while iPhone subjects are bound to regimes of work. It is also argued that news stories that emerged in the summer of 2007, when the iPhone was not released in Canada, structure a rhetoric of the "excluded Canadian."
\end{abstract}

Keywords: Mobile communication; Rhetoric; Visual communication

Résumé : L'adoption de nouveaux appareils mobiles mène à de nouvelles pratiques sociales. Cet article effectue une analyse serrée de la prétendue culture participative entourant les iPods et les iPhones. Il offre des lectures rhétoriques attentives de phénomènes objets tels que des publicités, des reportages canadiens et des réactions de la part de consommateurs dans les médias électroniques. Plus précisément, cet article démontre une transformation rhétorique entre la campagne publicitaire pour les Silhouettes d'iPod et la campagne pour les iPhones qui entraîne un changement de subjectivité : les utilisateurs d'iPods obtiennent une certaine mesure de liberté et de plaisir, tandis qu'on affecte ceux d'iPhones à un régime de travail. L'article soutient en outre que les nouvelles parues en été 2007, sur le fait que l'iPhone ne soit pas sorti au Canada, appuient une rhétorique du « Canadien exclu».

Mots clés : Communication mobile; Rhétorique; Communication visuelle

The launch of Apple Inc.'s iPhone in the United States was more than a new product release; it was a cultural event. Signalling its imminent arrival, an ad for the

Isabel Pedersen $(\mathrm{PhD})$ is an Assistant Professor of Professional Communication at Ryerson University. She is also affiliated with the Graduate Programme in Communication and Culture, a partnership of Ryerson University and York University. Email: ipederse@ryerson.ca.

Canadian Journal of Communication, Vol 33 (2008) 491-510 (C)2008 Canadian Journal of Communication Corporation 
iPhone ran during the 2007 Academy Awards and resurrected such stars as Lucille Ball, Humphrey Bogart, and Marilyn Monroe to build product desire (Elliot, 2007). People lined up all night for the June 29, 2007, release, and 500,000 iPhones were sold in the first weekend (Brinkley, 2007; CNN, 2007; Lee, 2007). Americans were not only lining up for an iPhone for its fetish appeal; they were also goaded to communicate with more mobile sophistication and to maintain their membership in an already established participatory consumer culture surrounding the iPod. ${ }^{1}$ As millions of Americans "lived" this event in mid-summer 2007, Canadians were utterly excluded from it. At that point, Apple Inc. did not release the iPhone in Canada and no date was set for its release. However, Canadians were exposed to the television advertising campaign as though they were to be included. Musing over postmodernism in a postmillennial context, Linda Hutcheon (2002), appropriating Fredric Jameson's terminology, writes, "As a Canadian, I have had to become accustomed to having our nation referred to . . . as the "semi-periphery of the American core' [Jameson's terminology]" (p. 8). The phenomenon surrounding the iPhone's prohibition from Canada in the summer of 2007 makes Hutcheon's/Jameson's descriptor tangibly obvious. Canadians, immersed actively in "iPod culture," found themselves sidelined from "iPhone culture." The fissure between this American event and Canadian nonevent serves as a rich site for a cultural analysis.

This paper uses the United States iPhone release on June 29, 2007, as a pivotal event in time. It argues that the deliberate birth of the iPhone amid the popularity of the iPod was not only a marketing feat, but also structured a shift in subjectivity. While the iPod campaign encourages a sense of embodied freedom and play, the iPhone campaign encourages a preoccupation with work and consumerism. This rhetorical manipulation has the potential to drive social practice surrounding these devices. However, I also argue that a so-called participatory culture surrounds these devices, affording the individual a voice for response, which I investigate through texts found on Web-based social networking sites. Last, I argue that the iPhone non-release led to patronizing portrayals of "excluded Canadians" in news stories. By pointing out this rhetoric of exclusion, I demonstrate not only the reaches of symbolic participation in this culture, but also one example of how this rhetoric functions and leads to specific consequences in a local context.

In order to treat this thesis, I combine several theoretical viewpoints of "participatory culture" (Andrejevic, 2004, 2007; du Gay, Hall, Janes, Mackay, \& Negus, 1997; Jenkins, 2006a). I offer extensive close readings of both iPod and iPhone advertisements to bring social, political, and historic context to the rhetoric instantiated in the Canadian news stories. These deliberate, subjective text selections suggest a degree of balance: the advertising is authored by Apple, the news stories by Canadian media. More simply, however, I draw this selection of texts from the kind of mainstream cultural artifacts that Canadians could consume during the summer of 2007, when the iPhone was not available to them in Canada. I also explore the possibility for consumer participation in this culture by pinpointing ways that consumers have authored new messages in reaction to it. Ultimately, this case study contributes to the growing research interest in mobile and device-driven culture in a specifically Canadian context. 
This paper takes a three-pronged approach to explore this cultural phenomenon. First, using resources of visual rhetoric (Arnheim, 1988; Kress \& van Leeuwen, 2006), it offers a close reading of specific ads from Apple's Silhouettes iPod advertising campaign to argue that the advertisements inculcate viewers through powerful manipulations of subject position. Second, this paper juxtaposes the Silhouettes iPod advertisements with selections from the iPhone's release advertising in order to chart the rhetorical transformations from one campaign to the other to reveal a significant shift in implied subjectivity. This part uses resources of rhetoric in order to expose this transformation (Burke, 1969). Third, this paper also attends deliberately to a global media phenomenon through a local cultural lens by looking at a set of 16 Canadian news stories limited to the summer of 2007, when very little information had emerged from Apple Inc. or telecommunications companies to explain the non-release of the iPhone in Canada. While many stories reported the American release of the iPhone on or close to June 29, 2007, this smaller set speculated on the significance of Canada's situation. This set constructs Canadians as ousted recently from the iPod party, pressing their noses on American windows with a quiet angst while the iPhone rolls out. The rhetoric of exclusion in popular texts such as newspaper stories functions not only to describe Canadian abandonment, but also to cause and construct it. I consider the "event" in these historic texts to ground the more conceptual, abstract claims of the first two parts of the paper, but also to argue that the iPhone's (non)release influences social practices in Canada and, to an extent, instigates off-putting portrayals of Canadians along a particular trajectory. These three parts, two that attend to a more general subjectivity instantiated in advertising campaigns, one that attends to a locally specific cultural event, taken together contribute to a greater understanding of not only mobile digital culture, but also how we as mobile subjects are manipulated directly by new device-driven cultures in local contextualized ways.

\section{Mobile culture and communication}

The iPod phenomenon is popular enough to generate mainstream social commentary. Leander Kahney's The Cult of iPod (2005) is an in-depth, non-academic treatment of iPods in everyday culture. It offers an historical perspective, situating the iPod craze within Apple's history of new products and advertising campaigns; it also discusses the iPod as a phenomenon in cultural terms. Dylan Jones' iPod, Therefore I Am: Thinking Inside the White Box (2005) is similar, but offers the author's more personal gaze on this cultural phenomenon. Geared to a general reading audience, both books instantiate a discourse of "iPodomania" to an extent, due to their celebratory, nearly gleeful approach.

In addition, much new scholarship has emerged concerning mobile communication in social and cultural terms (Caron \& Caronia, 2007; Gow \& Smith, 2006; Rheingold, 2002). Small Tech: The Culture of Digital Tools (Hawk, Rieder, \& Oviedo, 2008) focuses on mobile, miniaturized media in cultural, political, medial, and rhetorical contexts. In their introduction to this edited collection, Hawk, Rieder, \& Oviedo argue that the next wave of new media researchers will need to consider media and the "ecological interrelationships among the virtual space of the Internet, the enclosed space of the installation, and the open space of 
everyday life" (2008, p. ix). As mobile devices deal more and more with the human body in a moving context (e.g., human temperature readings, heart rate during extreme physical activity, and geographic location on a GPS system), in addition to the more traditional expectations of a mobile device (e.g., phone, messaging, camera), they will require vigilance not only in terms of personal privacy, but also in terms of potential cultural manipulations. Steve Mann (2001) suggests that we need to shift the balance of power significantly away from computing machines and place agency in the hands of human users, who are always moving. His Cyborg: Digital Destiny and Human Possibility in the Age of the Wearable Computer (2001) is canonical to the field, particularly because it presents concepts for mobile, wearable devices upon which other inventors draw. Its highly political stance criticizes surveillance society and positions the mobile computer as a countersurveillance tool. It also recounts Mann's culture-jamming stunts and anti-establishment interventions, making him the mobile computer hero of media studies writers such as Paul Virilio, who calls Mann "a benign forerunner of the Unabomber" (2000, p. 98).

My article, working along similar lines to this growing scholarship in mobile, wireless communication, attends to several artifacts that instantiate different forms of participation with iPod/iPhone culture. Its rhetorical interrogations lead me to demonstrate how new media cultures bleed into everyday social practice and alter everyday contexts.

\section{Participatory media culture}

It is arguable that a participatory culture surrounds the iPod that ultimately helped shape the expectations surrounding the iPhone release. This paper offers three different perspectives concerning the question of whether or not media can engender participation. The first view affords people a measure of participatory agency. Henry Jenkins' Convergence Culture (2006a) triangulates "media convergence" with the process of "participatory culture" and "collective intelligence" in a way relevant to this discussion. He writes:

The term, participatory culture, contrasts with older notions of passive media spectatorship. Rather than talking about media producers and consumers as occupying separate roles, we might now see them as participants who interact with each other according to a new set of rules that none of us fully understands. Not all participants are created equal. Corporations - and even individuals within corporate media-still exert greater power than any individual consumer or even the aggregate of consumers. . . Consumption has become a collective process. (p. 3)

Drawing on his other works concerning "fandom," Jenkins $(1992,2006 \mathrm{~b})$ in his new book deals with how consumers of one medium participate in activities that require individual and collective consumption of, participation in, and even contribution to the content of multiple media. For example, one of his chapters charts how the Matrix film series demanded that film-goers play certain video games, contribute to discussion groups, and view animated shorts in order to understand the complete mythology of the films (Jenkins, 2006a). Participation, in this case, fulfills the goals of the film company, leading to a forced conver- 
gence surrounding the films. Jenkins also reveals ways that countercultural and political movements trumpet alternative views in this new participatory relationship, promoting ends that lie with individuals. Even though he discusses how people contribute to media content, partaking in political activism or fandom through convergence, Jenkins rejects a completely naïve view of individuals as autonomous agents of media change. Conversely, he argues that cultural participation is socially driven and unpredictable, and that media convergence is still very much mediated by regimes of the state and the market.

I draw a second view of participatory culture from Mark Andrejevic, who rejects Jenkins' notion of participatory culture, calling some of Jenkins' earlier work on it "celebratory descriptions of fan activity" and "obverse" to his own treatment (Andrejevic, 2007, pp. 137-138). Andrejevic (2004) writes of reality TV media that it is "a form of production wherein consumers are invited to sell access to their personal lives in a way not dissimilar to that in which they sell their labor power. ... [T] he promise of "reality as a form of 'collaborative' production clearly has its limits" (p. 6). In this model, then, cultural participation is always a commoditized activity; participation is the act of selling and buying. Andrejevic (2007) argues that new portable devices such as cellular PDAs, cellphones, and iPods, which are so integrated with our homes, cars, and jobs, enable a further degree of surveillance on the part of corporations and law enforcement. These new "space-time paths" of users become "fine-grained forms of social sorting, customization, and surveillance" (p. 94). In this configuration, we have spawned a new form of social control much more insidious than that generated by our previous desktop-docked culture. Participation is a fabricated ruse.

Other writers who question Jenkins' notion of participatory culture include Sinnreich (2007), who applauds Jenkins (2006a) for recognizing "the analogy between contemporary changes in media aesthetics, communication infrastructure, organizational logic, media consumption habits, and the balance of cultural power," but criticizes Jenkins for missing "the connective tissue - some kind of hypothetical mechanism tying them all together. We must ultimately take it on faith that these events are somehow united by the geist of convergence" (Sinnreich, 2007, p. 44). He also takes Jenkins to task over assumptions concerning audience empowerment and the extent of individual agency. One way to connect the mechanism of convergence is to return to notions of culture as symbolic action subject to hierarchically driven discourses where, nevertheless, transformations occur (Barthes, 1972, 1978; Goldman \& Papson, 1998).

Keeping this point in mind, a third view of participatory culture might be gleaned from another exemplary text. Doing Cultural Studies: The Story of the Sony Walkman (du Gay et al., 1997) offers an apt description of the Sony Walkman as a symbolic artifact operating in terms of cultural context:

The Sony Walkman is not only part of our culture. It has a distinct "culture" of its own. Around the Walkman there has developed a distinctive set of meanings and practices. The very word "WALK-MAN" conjures up an image, or an idea - a concept - of the device. We can then use the concept to think about it, or use the word (or image or drawing or sculpture or whatever) as a sign or symbol which we can communicate about 
to other people in a variety of different contexts, even though we may never have owned or operated one. It belongs to our culture because we have constructed for it a little world of meaning. (p. 10)

Exhuming images of roller-skating, disco-dancing, walkman-toting subjects, du Gay et al. (1997) discuss the Walkman as a loaded cultural signifier. Like Walkman culture, iPod culture implies a context instantiated by myriad texts, a "little world of meaning." Texts might include massive urban billboard advertising, encounters with iPod wearers on subways, exposure to print-based advertising, politically instigative iPod t-shirts, or Apple press releases. Dealing with one text, then, is also always a negotiation with a social context of texts very much embedded in the unpredictable lives of humans. Not all Canadians own an iPod, many plan never to buy an iPhone, but the texts that I choose to analyze for this paper form part of a broader cultural context that goes far beyond the devices themselves.

Taken together, each of these three views of culture as participatory is illuminating. In keeping with Jenkins' (2006a) view, I will explore ways that everyday individuals participate and intervene in the workings of media culture. However, I bring to the discussion the caveat that participation is symbolic and always contextualized in meaning-making systems that reach far beyond the devices themselves (du Gay et al., 1997). Ultimately, participation is also always commoditized (Andrejevic, 2007); cultural production surrounding iPod/iPhone devices never skirts commercial ends.

Rhetoric is another term key to the argument. Drawing on the work of Kenneth Burke and Pierre Bourdieu, Glenn Stillar (1998) views rhetoric as a transformative social process in language that ultimately changes people's minds or induces actions in addressed human subjects. Stillar concentrates on texts such as cereal boxes, print advertisements, and bank brochures to point out the subtle rhetorical manipulations that people experience in their everyday lives through the language that surrounds them. Stillar's notion of rhetoric helps me identify a reticent rhetorical undercurrent and bring to light its subjective implications in a very specific way. After dealing with advertising in the first two parts of this paper, the third part culminates in a discussion of how "Canadians" are fashioned into an excluded totality by a set of Canadian newspaper stories. The word "exclusion" comes from the Latin claudere, meaning to close or bar from participation. Exclusion can also imply being expelled from a place inhabited previously, from previous "inclusion." It is this double meaning that makes the word so fitting in this case, rather than "marginalization" or "segregation," which imply much more concrete positioning. By using the term exclusion (with its implications of inclusion), we can acknowledge the shifting, transient nature of participation in social memberships that iPod/iPhone culture implies.

\section{The iPod}

Released in 2001, the iPod is Apple Inc.'s version of the portable media player. It comes in several sizes with different capacities, and as such, really constitutes a suite of products. In 2003, Apple Inc. launched its iPod Silhouettes advertising campaign in urban places such as Paris, Berlin, Amsterdam, New York, Los Angeles, Montréal, and Birmingham, U.K. To call the iPod "popular" would be 
a somewhat ridiculous oversimplification; Apple reported in 2007 that it had sold 100 million iPods (Apple Inc., 2007a). Conceptually, the iPod has grown beyond being purely an audio device; it stores files, displays text, plays video, plugs into stereo systems, and facilitates user movement because of its tiny size and socalled "intuitive wheel interface." Kahney (2005) explores the rise of the iPod phenomenon in The Cult of the iPod:

The iPod is used to invoke euphoria. People are in love with music. The sparkling genius of the iPod is that it gives it to you in huge doses. The iPod can store an entire lifetime's worth of music. And so it becomes the most personal of personal devices. More than a computer, a car, or a fancy pair of shoes, it's part of your makeup, your personality. What's on itthe music - tells who you are. Music is deep in your heart and soul. (p. 3)

Putting aside Kahney's overt adoration, one can extract relevant concepts in this passage. iPods signify a high degree of self-centricity; they are "the most personal of personal devices." The music on the device "tells who you are." The iPod's aggressive advertising campaign, the creative brainchild of TBWA $\backslash$ Chiat\Day, Apple's long-standing ad firm, authors this rhetoric. Jones (2005) writes about self-centricity in the iPod advertising campaign in his book, iPod, Therefore I Am:

The advertising of the product was crucial, and needed to set the machine apart from everything else in the market. Apple's brief to New York-based ad agency TBWA/Chiat/Day was simple: empower the individual. Unlike every other aspect of the computer world, the iPod had little to do with togetherness, had little to do with community spirit. The iPod was all about individuality and personal space. (p. 67)

Jones explains that Apple wished to counter Internet culture (i.e., a culture that connects everyone with one big network) with its ads in order to structure new strategies of user identification based very much on the fantasy of private spaces and personal empowerment.

"Centricity" is also the key visual concept to the iPod Silhouettes advertising. With some variation, the television ads depict lone, dancing, silhouetted subjects moving across a horizonless space. Limbs are rays emanating from the centres of the body. Likewise, the print ads structure the same movement in a static context by catching human subjects in frozen moments of the dance; vectors of elbows and knees stretch outward from the subjects, defining the compositions. Centricity is a complex visual process tied closely to social practice. Visual rhetorician Rudolf Arnheim (1988) writes, "As I discussed matters of visual shape with students and other audiences, I began to see that the interaction of centricity and eccentricity directly reflected the twofold tasks of human beings, namely, the spread of action from the generating core of the self and the interaction with other such centres in the social field" (p. ix). By enlisting centricity, the iPod ads structure a worldview in which the iPod wearer not only solely inhabits, but also controls and ultimately governs his or her own space without outside influence.

One technique that Apple, as a rhetor, enlists is the depiction of visual nontransactional processes. Gunther Kress \& Theo van Leeuwen (2006) explain that 
"the action in a non-transactional process has no 'Goal' because it is not 'done to' or 'aimed at' anyone or anything. The non-transactional process is therefore analogous to the intransitive verb in language (the verb that does not take an object)" (p. 63). In other words, the iPod subjects simply live and dance; they do not exist for any other objectified reason, they simply exist. Non-transactional actors in images can exude confidence and omniscience in that they seem to know something about their existence that we, the ignorant viewer, cannot see. In the iPod ads, we are not party to the reasons behind the dance; we only see the exuberant and alluring energy played out in front of us. These dancers are living, moving subjects and not much more than that; they achieve the everyone/anyone appeal that Apple clearly wants to signify. iPods involve lives rather than work, and they conceptually overturn common computing paradigms, which focus on what a computer can do for you.

Interestingly, the famous Canadian Telus/Clearnet campaign enlisted centricity as a conceptualizing technique to advertise mobile phone plans in the first half of the decade (Pedersen, 2006). The signature leaping, red-eyed tree frogs of the Telus/Clearnet campaign signified centricity and dynamic energy. Like the iPod dancers, the Telus frogs leapt with all four limbs stretched outward, like a radiating sun across a horizonless white backdrop. Telus, however, employed connotative processes to present a mobile worldview; metaphoric animals moved freely in their white world, signifying the kinds of movement that humans might enact. The words accompanying the early ads nudged consumers with taglines such as "Halifax, you're free!" Conversely, the Apple iPod ads are always denotative. They always use human subjects, and they always depict the iPod device in the ad, even if it is a highly abstract silhouetted version.

Centric compositions also make potent the locative semiotics of the campaign, driving mainstream participatory response in subtle ways. For several

Figure 1: iPod ad on Spadina Ave. Toronto

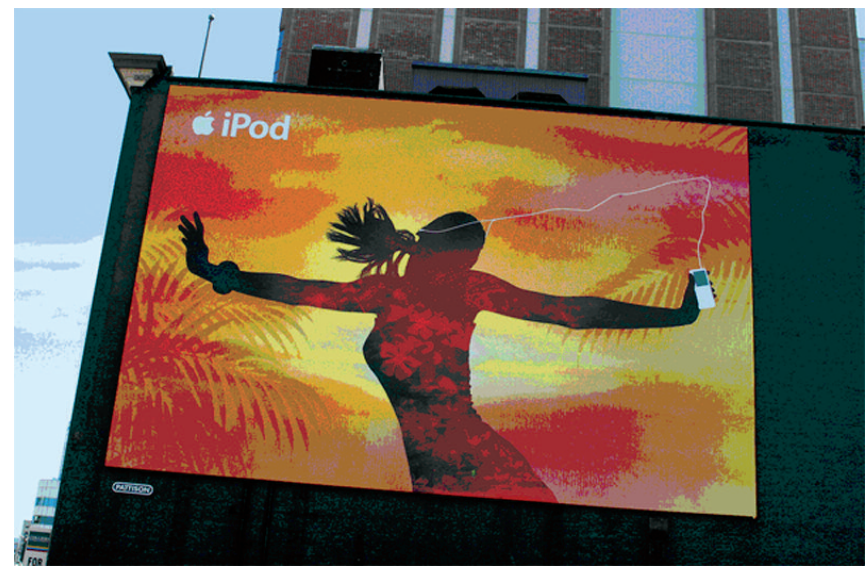

Photo Credit: motionblur studios www.motionblurstudios.com (Creative Commons licence) 
years, the campaign infiltrated Toronto streets and the subway's netherworlds, encoding the city with embodiments of "iPodness." By capturing these images and saving them, amateur photographers demonstrate viewer fascination with these ads, signalling a form of participatory consumption (see Figures 1 and 2).

To an extent, walking around downtown Toronto means engaging with a cultural context that is thrust on the pedestrian. iPod culture draws from and contributes to local cultural configurations to the point that it becomes an aspect of Toronto's urban experience. While these ads are commercially compelling and visually overbearing, they are (dare one say it) pleasant art pieces breaking the monotony of grey cement and mortar. They demonstrate Apple's rhetorical strategy of placement; they reveal the deliberate mapping of the pedestrian footfall in conjunction with the placed visual text. Consequently, Torontonians walk iPod culture as much as they wear it.

Working alongside Apple's orchestration, mainstream consumer responses to the campaign appear in social media venues, including Flickr, Facebook, and some weblogs. Figure 2, "Toronto - iPod city," by amateur photographer Joseph Hurtado (2007), appears on his page at Flickr.com, a popular photo-sharing website. While Hurtado's photograph is associated with fan-based Flickr groups such as "iPod Love" and "Design (Your iPod CREATIVE)," it also reports membership in more mainstream groups like "Toronto 2007," "Torontoist," and "BlogTO (Toronto)." Identifying a documentary motive, Toronto 2007 claims that its photos "will help everyone who looks at them understand what happened and what Toronto looked like in 2007" ("Toronto 2007," 2007). BlogTO (Toronto) simply aims to instantiate notions of Toronto identity when people share "their photos of Toronto with Toronto" ("BlogTO [Toronto]," 2008). It would be naïve to say that Hurtado's photograph signifies some sort of global media intervention; at the same time, it would be dismissive to ignore its aesthetic goal, which is to capture

Figure 2: Toronto-iPod city

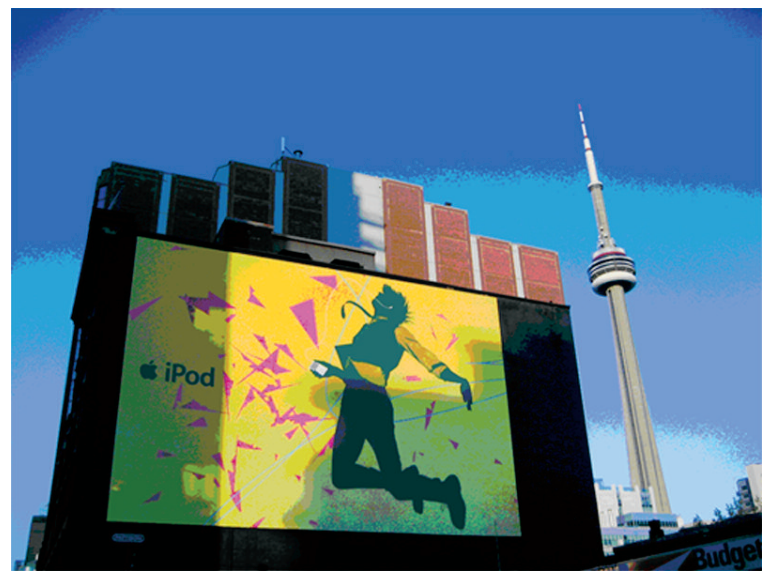

(flickr.com member "trumpetflickr”) 
a local cultural dialogue with Apple's monolithic commercial imposition. By chiming into this dialogue with his photograph and his deliberate composition, Hurtado exemplifies the subtle workings of this participatory cultural phenomenon as a context of meaning-exchange.

Cultural participation takes other forms. The iPod visual silhouette is a powerful meaning-maker, appropriated by many as a countercultural signifier often circulated in the form of online JPEGs and offline posters (see Figures 3 and 4). The use of the iPod imagery for countercultural purposes is not simply a jab at Apple; often the frame is appropriated for political ends unrelated to the company, but geared to political instigation and social commentary.

In Figure 3, the artist enlists centricity for this piece, but chooses centripetal rather than centrifugal forces to achieve juxtapositional irony. The "caved-in," starving child jars our expectations and signifies stasis inside a frame that normally emphasizes movement and centrifugal action. The image successfully generates the pathos it aims to achieve. Similarly, the "iRaq" set of "guerilla posters" promotes anti-war sentiments by depicting images of war prisoners using the iPod silhouette (see Figure 4). Like the starving child, the torture victim repulses us, achieving the artist's intended irony and feeling of mortification.

The late nineties saw the emergence of a "culture jamming" movement (Carducci, 2006; Frazier, 2007; Lasn, 2000; Soar, 2002), which is the "appropriation of a brand identity or advertising for subversive, often political, intent" (Carducci, 2006, p. 117). Soar (2002) writes of culture jamming and the role of graphic designers as cultural intermediaries, producing the graphics for corporate brands by day, and countering them by night through provocative art pieces in magazines such as Adbusters. To an extent, "iFamine" generates its own jam. Its exposure on Flickr led not only to individual responses by people, but also to further appropriation, by a site called "Art Threat" that describes itself in countering terms: "Set against a cultural landscape saturated with profit pop and reality TV,

Figure 3: iFamine

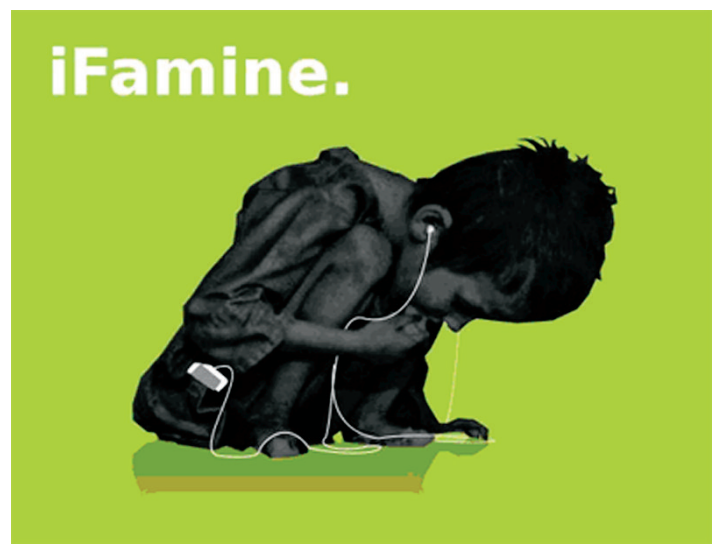

Photo Credit: Andrew Mason (Creative Commons licence) 
Art Threat is a website about political art. We showcase political artists who mix art and politics to create artwork seeking social change" (Art Threat, 2008).

On the whole, these cultural manipulations demonstrate how iPod culture, with its centric subject positioning, extends well beyond an advertising campaign, allowing participants to appropriate and circulate content in other media. These examples point directly to the sort of participatory symbolic backlash that Jenkins (2006a) identifies. However, these appropriations also simultaneously constitute a corporate worldview, promoting Apple as much as they seek to counter societal complacency. In keeping with Andrejevic's (2007) model, any rhetorical act that draws on "iPodified" meaning, even the politically instigative, is never free from promoting Apple's commercial end. These countercultural exercises exhibit the means through which we are inculcated by discourses governing the ways we both perform through text and become goaded by it.

\section{The iPhone}

The iPhone emerged as a cultural phenomenon when it was first announced by Steve Jobs, Apple's Chief Executive Officer, on January 9, 2007, and the advertising campaign followed closely afterwards (Musgrove, 2007). Strategically succinct, the release campaign focused on features and usage, rather than promoting any technical information about the device. One of the early iPhone television ads, Never Been an iPod (Apple Inc., 2007c), echoes the phrase "there has never been an iPod that can do this" throughout the ad, goading the viewer to identify with all the "gee whiz" features of the new device. It is the sort of strategy a competitor would use to piggy-back an emerging product upon a competitor's more successful one. The 7UP "uncola" advertising in the 1980s leveraged the popularity of the colas, Coca-cola and Pepsi, with a similar flippant negation to build the 7UP brand. However, Apple uses this odd rhetorical reversal to make the iPhone ontologically dependent on the iPod. In these commercials, Apple forms this dialectical gap to emphasize that one can use an iPhone to browse the Internet, send and receive email, take digital photographs, and speak to other people-all things that an iPod cannot do. But the commercial implies that the iPhone is still an iPod, offering all of the file-storing and playback capabilities that the iPod offers. By creating this dialectic over both identification with and denial of the iPod, Apple establishes early consumer recognition for the iPhone.

Quite strategically, however, the "never been an iPod" phrase also constitutes what Burke terms "transcendence" (1969, p. 189). In writing about the workings of a dialectic, he explains that rhetoric can function to transcend the polarity of terms, both fulfilling the conflict of the dialectic and re-ordering it (p. 189). Apple uses a calm male voice in the Never Been an iPod television ad to enact this kind of transcendence. This omniscient narrator, the voice of Apple itself, quells the jangle between the iPod and iPhone, transcending the dialectic completely. Consumers, ultimately, are goaded to desire both products, never thinking poorly of either one.

Like the iPod print and television advertising, the iPhone advertising still features a familiar visual persona in all of its ads. However, Apple replaces the iPod dancers with a single arm and hand that thrusts upward from the bottom of the page/screen, clutching the iPhone. The amputated hand acts as a synecdochic 
stand-in for a now-static body. Occasionally, the other hand points and touches the iPhone device in the television advertising, but the (imaginary) body stands still. The hand and device seem to form one entity that "stares" outward at the viewer, forming what Kress \& van Leeuwen (2006) term a "demand" gaze (p. 118). The demand usually involves a depicted human subject locking eyes on the viewer; nevertheless, the frontal horizontal angle and the neutral vertical angle of the iPhone composition also form a demand, compelling the viewer to see an anthropomorphized being requiring action, e.g., "Look at me. Look what I can do. Buy me." The iPhone certainly displaces the human dancer of the iPod ads.

Figure 4: iRaq

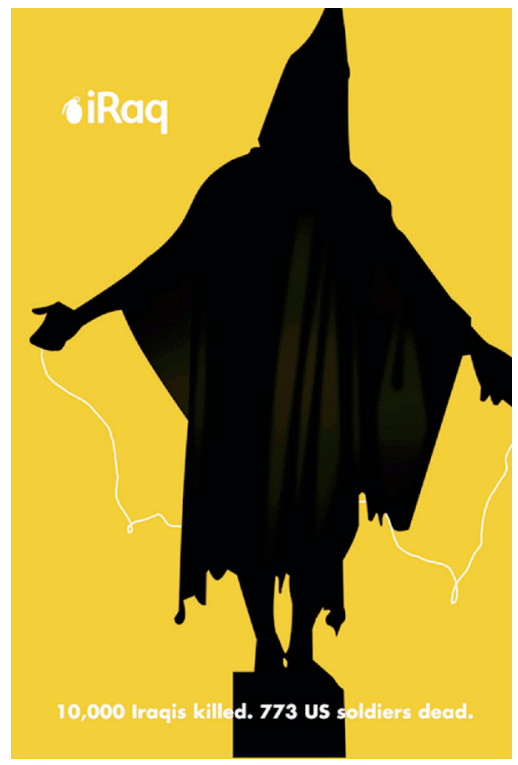

Photo Credit: www.forkscrew.com/main.html

While advertising firmly establishes the iPod subject as centric, iPhone advertising emphasizes the eccentric. According to Arnheim (1988), the eccentric system deals with how a primary centre acknowledges others in visual compositions:

$[\mathrm{T}]$ he nature of the vector, represented by our own arrow, changes. It is no longer a mere passive emanation of energy released into empty space but rather an active goal-directed aiming at a target, a striving to approach that may be friendly, like a longing, or hostile, like an attack. (p. 5)

Eccentricity is one means through which we can identify "relatedness" in static visual compositions. To point at something or someone is to demonstrate a relationship between visual entities. When the secondary iPhone hand begins keying in numbers or touching the screen, it acknowledges the device as a deliberate target. The iPhone subject becomes eccentric.

Further, the iPhone hand is synecdochic for human work. While the iPod subject is liberated from work activity and has moved on to living in terms of music, 
the iPhone subject has been called back to work. The eccentric fingers work over email, calendar-building, navigating Google maps, and buying media content. Another of the early iPhone ads, called "Calamari" (Apple Inc., 2007b), pleasantly describes the sensation of watching a film, only to be stirred to hunger by one of the evocative scenes. In this case, sea serpents in the Pirates of the Caribbean film rouse the narrator to find a calamari-serving restaurant. Gustatorial desire segues to a demonstration of the device's searching and mapping features. Ultimately, the ad subtly depicts the subject's transformation toward good consumerism; actions seem to end in some sort of purchase.

In keeping with Andrejevic's cultural model, hegemonies of consumerism bind cultural practices surrounding both the iPod and the iPhone. To tote either is to participate through product ownership. However, the rhetorical transformation that takes place from one campaign to the other signifies an alteration of subject position to a further degree of inculcation. On the whole, the iPod Silhouettes campaign structures participants who are centrically driven and unbounded by the composition. Metaphorically, they represent a degree of freedom. Conversely, the iPhone campaign structures a work-driven subject whose actions must lead to a commercial end. The eccentricity of the composition acknowledges subjects as social, but it also renders subjectivity somewhat generic. By reducing the subject to an arm, a working arm, subjectivity becomes debased.

While the iPod Silhouettes campaign leaves open the door for countercultural, participatory interrogation based partly on its visual rhetoric, the iPhone does not seem to instigate the same type of extreme reaction. There are YouTube iPhone spoofs of the television campaign demonstrating cultural participation; however, they focus more on humour bound within regimes of the blockbuster film or television sitcom. Many spoofs use YouTube video for collective complaints about technical aspects. "iPhone Parody No Flash" ("iphonenoflash," 2007) mimics a release ad in order to complain that Adobe Flash technology does not work on iPhones. Reporting 156,278 views, it is the sort of consumer response driven by interested customers trying to make better the device they own.

A plethora of texts, each exhibiting a plethora of motives, instantiate a participatory culture surrounding the iPod/iPhone. In this section, I have traced the rhetorical momentum that goes on between the two ad campaigns, which ultimately binds the subject within a metaphoric work domain. I have placed this rhetorical transformation across a backdrop of consumer-driven responses to these campaigns in order to explore the opportunity for consumer intervention that Jenkins suggests is possible. And I argue that as we become used by Apple the rhetor, we can simultaneously use Apple to channel our social commentary. The next part of the paper moves away from the more abstract visual analysis to look at news stories, another kind of cultural text, to identify the rhetorical act of exclusion at a very specific point in time.

\section{iPhone and summer 2007}

As the June 29, 2007, iPhone launch approached, Canadian news stories regarding the event emerged. Over this time, most Canadian newspapers simply picked up stories from international newswires, reporting the release as an American event, which is rhetorically significant in and of itself. However, this paper con- 
centrates on stories that framed the American release as a Canadian story. It concentrates on those that dealt with the first shock that Apple would not bring the iPhone to Canada in the summer of 2007. It traces themes across 16 print newspaper stories focusing on the launch (including different versions of the same story), which appeared in Calgary Herald, Harbour City Star, The Edmonton Journal, The Gazette, The Globe and Mail, Ottawa Citizen, Times \& Transcript, The Vancouver Sun, The Toronto Star, and Winnipeg Free Press (see list of Canadian news stories). This selection of stories is by no means exhaustive; on the contrary, it takes a snapshot of the response between June 22 and August 11, 2007, concentrating largely on the last week in June. This last part of the paper culminates my analysis of participatory iPod/iPhone culture by charting instances of cultural indignity. The rhetoric of exclusion in these mainstream news stories functions not only to describe Canadian exclusion, but also to construct Canadians as excluded, which is an entirely different rhetorical act and one that proves the significance of this device-driven culture. The iPhone's (non)release instigates inimical portrayals of Canadians in the news.

Initially, some news stories responded with outright enthusiasm over the iPhone's coming, along with the recognition that it would not be sold in Canada. Canadian Globe and Mail columnist Barrie McKenna (2007) philosophizes over whether it will be labelled a "disruptive innovation' . . a new product so advanced and appealing that it displaces the technology that preceded it" (p. B18). Marc Saltzman writes on June 23, 2007, in Montréal's Gazette:

Unless your white iPod earphones have been stuck in your ears over the past six months, no doubt by now you've heard Apple is about to launch the most eagerly anticipated gadget of the year - if not in the history of the consumer electronics industry. . . . That sound you just heard was millions of gadget geeks salivating. But if you're Canadian you can save your energy. (p. I1)

Immediately following, and sometimes in conjunction with, this initial anticipation, Canadian writers voiced disappointment that Canada would not be part of the American launch. Pilieci writes in the Ottawa Citizen that "complaints from Canadians about its lack of availability are jamming Internet chat rooms" (2007, p. D1). Sorensen writes in The Toronto Star that "there remains scant information about when Canadians can get their hands on the sleek devices-a situation that appears as frustrating for wireless carriers as it is for gadget-crazed consumers" (2007, p. B1). These overt comments make obvious consumers' expectations.

In some news stories, the rhetoric is subtle, nearly reticent, but also revelatory. Montréal's Gazette editors provide a Canadian contextualizing lead-in to a story written by Michelle Quinn of the Los Angeles Times:

Waiting can have its virtues, it seems. While Canadians are stuck waiting for details on when Apple's much-hyped iPhone will be available here, at least they are being spared the challenges new U.S. owners are facing. Fuelled by caffeine and curiosity, more than 300 laptop-wielding U.S. tech geeks filled a borrowed office last weekend to unlock some of those iPhone mysteries. (Quinn, 2007, p. I2) 
This snippet portrays Canadians as meek, quiet, good, and subordinate to "U.S. owners," who are "challenge[d]," "fuelled," "curious," and knowledgeable. Owners are also identified as renegade code-crackers taking matters into their own hands, who trick Apple out of its "mysteries," or the power relationship imposed by the artifact itself, while Canadians remain goaded and powerless. When given the device, "U.S. owners" exhibit the sort of signs that Jenkins identifies as "participatory"; they consume the device and appropriate it immediately for other potential ends. Other stories conceptualize Canadians as enviers, coveting the iPhone as an American treasure, clearly conscious of their outsider status (Pilieci, 2007, p. D1).

Many stories simply focus on the technology itself; this one from Moncton, New Brunswick's Times \& Transcript privileges the features:

Technology giant Apple has launched the new iPhone in the United States, although consumers in Canada may have to wait to get their hands on the product.

Boasting such features as a 3.5-inch widescreen multi-touch display, wireless internet capabilities, a 4 or $8 \mathrm{~GB}$ flash drive and multiple video supports, it is the newest in leading edge all-in-one hand-held technology.

The product was released yesterday at Apple retailers across the United States, but no such plans are currently set for release in Canada. ("No iPhones for Canadians; Apple's newest technology hasn't been released in this country," 2007, p. D2)

In these product release stories, the star-struck writer fuels Canadian angst with an ethos-padding list of the iPhones' features, building the rhetoric of exclusion to ever greater degrees. Even more than the features, the descriptive modifiers are revealing; phrases such as "the newest in leading edge all-in-one hand-held technology" strand the excluded in contexts of the oldest technology, followers rather than leaders. Apple's agency exhibits itself not only in its power to "launch" the iPhone wherever it chooses, but also in its ability to include or exclude whatever nation it chooses with ease.

The iPhone release stories portray Canadians in one of the most curious of double binds. These writers depict "Canadians" as a sidelined horde because of their exclusion from their previous commercially colonized situation. They fashion angst that largely springs from the feeling of being passed over by the hegemonic ordering to which one is normally subjectified. One Winnipeg Free Press writer sums up the sentiment in his story "No Apple iPhone? You Must Be Canadian":

Here's a list of things you can't get in Canada: Apple's iPhone, the overthe-counter anti-inflammatory drug, Aleve, HBO, Mercury cars, TiVo, private medical care, the ability to download or stream most popular American TV shows. The list is not exhaustive nor is there a single reason why the articles and services are unavailable, but they are all available in the United States. The list does, however, illustrate my growing level of irritation that living north of a certain border means missing out. (Hirst, 2007, p. A11) 
Writing on August 2, 2007, well after the American release, Hirst identifies Canadians as ousted from familiar mass commercial contexts and expresses personal irritation. With the iPhone, this portrayal of exclusion takes on greater meaning because Canadians were full participants in iPod culture before the iPhone release. Hirst's complaint makes me recall Andrejevic's (2007) model of culture as an enclosure of commercial and state surveillance. It demonstrates that we openly expect commercial agents to ensnare us and fulfill our commercial desires, and we become incensed when overlooked by them, further demonstrating our complicity with the model of consuming as participating.

Perhaps the most telling sign that Canadian writers (or Canadian news sources) structured their own image of exclusion in the summer of 2007 is the fact that this non-event was considered newsworthy in the first place. Product releases occur all over the world from which Canadians are excluded, and they likely do not make the Canadian news. However, to structure Canadians as "missing out" means to come close to inclusion, to understand one's rightful place in the line, and then to be passed over. Whether overtly or covertly, all of these news stories carry the sentiment of the "missed-out" Canadian. And interestingly, many of them express faith that Apple will release the iPhone in Canada in due time, signalling continued identification with iPod/iPhone participatory culture.

On June 29, 2008, one year later, a blog columnist from CNN's Fortune magazine website writes about the upcoming Canadian release (Elmer-DeWitt, 2008), making it an American story. The writer opens with history: "It's taken more than a year for the iPhone to make its way across the world's longest undefended border, which may help explain why so many Canadians are upset this weekend," and he recounts the year of frustration that followed from the summer of 2007. The story peaks with another event: the fact that 30,000 people signed an "open letter" to Apple's Steve Jobs complaining that the Canadian iPhone carrier, Rogers Communications Inc., will be charging too much for wireless service plans when iPhones go on sale in Canada. It reads:

Dear Steve,

My name is James and I would like to thank you for creating the wonderful iPhone device. We really think that you will change the world with it, just as you changed the world with the iPod. We were so happy to learn that on July 11 th, we would finally be able to buy the iPhone and legally use it in Canada.

To our great disappointment, Rogers Communications Inc. has announced VERY unfair rates in comparison to AT\&T in the United States and to other authorized wireless service providers around the world. As a result, a consumer movement was born yesterday (June 27th) in protest against these rates.

More than 20,000 people have signed an online petition to help make a difference and the list is growing rapidly. In the last 72 hours, the website has had 150,000 unique visitors from around the world supporting Canadian consumers. There are a vast number of Canadians that would take the opportunity to buy an iPhone at \$199CAD but these new plans 
have put it out of reach for many.

I would like to invite you to take a look at all these disappointed people at www.ruinediphone.com.

I was going to buy an iPhone for me, my girlfriend and my family.

Now, sadly, I cannot afford the plan.

I hope you can do something Steve; we are loyal customers and trust that you will. We don't want to lose faith in Apple.

Thank you,

James Hallen

Representing more than 20,000 Canadian consumers.

(Hallen, 2008)

Parodic of a "Dear God" letter, this petition signed by Hallen and, eventually, 60,000 others relieves a year's worth of collective stress. On the whole, the irony marks a new sense of inclusion. The group authorizes its countercultural activities under the label of a born "consumer movement." It uses its former exclusion as both an object of humorous self-mockery and of sincere complaint. It asks for parental-style interference when dealing with Rogers, a transgressive wireless carrier (e.g., "now that we count ourselves among your consumers, we ask for your divine intervention"). Its closing threat, the potential for "los[ing] faith in Apple," would mean deliberately severing cultural affiliations with the economy of all things iPhone. In the end, the group lobs the threat of a self-imposed exclusion back at Apple.

\section{Conclusion}

Participatory culture operates across a multitude of symbolic contexts. This paper investigates this premise by analyzing company-sanctioned ad campaigns alongside consumer responses and political reactions to those same campaigns. It has explored Canadian news stories dealing with Canadian exclusion from iPhone consumerism alongside a consumer backlash petition over the terms of Canada's subsequent inclusion. Each textual outcome bears consequences.

The iPod Silhouettes campaign carves an ideal view of the mobile subject. It tantalizes us through its presentations of liberty, centricity, and emancipation. However, the iPhone release advertising cuts in the opposite direction. While the product itself gives actual users more opportunities for social interaction, the visual rhetoric restrains the subject with hegemonic ordering. The iPhone working hand usurps the iPod moving body. The transformation from iPod subjectivity to iPhone subjectivity is revelatory; its "ideal to real" trajectory betrays ongoing inculcation of the subject in the same banal orders of work and commerce that ground the subject's commonplace existence. As I have argued, the transformation from one campaign to the other ultimately persuades us that we want to consume both devices.

Canada's exclusion from the iPhone release in the summer of 2007 was like snatching candy back from a baby. The iPod/iPhone phenomenon reveals the argument that mobile participatory culture with its seemingly global perspective 
has local implications for everyday people. Ultimately, participatory culture is a goading symbolic regime. As mobile subjects, we instantiate new social practices in conjunction with our new digital devices.

\section{Note}

1. The 2007 version of the iPod is a wearable personal device designed for listening to music, watching video, and storing files. It operates as a stand-alone device; the user is not networked to any server while using it as a player. The 2007 version of the iPhone offers more interactive features, including wireless access to the Internet and cellular phone capacity. Both are Apple Inc. products. Even though I limit my analysis to the summer of 2007, I acknowledge that upgrades for both devices have been released and hybrid products like the iPod "Touch" have emerged. Likewise, the advertising campaigns have transformed to reflect these new renditions.

\section{List of Canadian news stories under analysis}

Anderson, Fiona. (2007, July 14). iPhone woes. The Vancouver Sun, p. D1.

Cordery, Walter. (2007, June 30). iPhones won't be here until '08. Harbour City Star (Nanaimo, BC), p. A4.

Hirst, Nicholas. (2007, August 2). No Apple iPhone? You must be Canadian. Winnipeg Free Press, p. A11.

Marck, Paul. (2007, June 22). iPhone puts Canada on hold. Edmonton Journal, p. E1.

Versions in other papers:

Marck, Paul. (2007, June 23). Canadians await launch of much-hyped iPhone. Winnipeg Free Press, p. B9.

Marck, Paul. (2007, June 23). Sellers expect the iPhone to hit Canada this summer. The Vancouver Sun, p. F4.

Marck, Paul. (2007, June 23). July likely arrival date of iPhone in Canada. Calgary Herald, p. C9.

McKenna, Barrie. (2007, June 26). Will iPhone change everything — or fall flat? The Globe and Mail, p. B18.

No iPhones for Canadians. (2007, June 30). Times \& Transcript (Moncton, NB), p. D2.

Pilieci, Vito. (2007, June 28). Canada's iWait will continue. Ottawa Citizen, p. D1.

Versions in other papers:

Pilieci, Vito. (2007, June 28). Apple's iPhone launch leaves Canadians i-envious. The Vancouver Sun, p. F5.

Pilieci, Vito. (2007, June 30). Canadians left out of rush for iPhone. Calgary Herald, p. D7.

Quinn, Michelle. (2007, July 14). While Canadians wait for iPhone, Americans try to break the code. The Gazette (Montréal, QC), p. I2.

Rocha, Roberto. (2007, August 11). In Canada, iPhone is still a paperweight. The Gazette (Montréal, QC), p. C2.

Saltzman, Marc. (2007, June 23). Why the iPhone is on hold in Canada. The Gazette (Montréal, QC), p. I1.

Sorensen, Chris. (2007, June 28). Apple sets out to sell iPhone by its rules. The Toronto Star, p. B1.

\section{References}

Andrejevic, Mark. (2004). Reality TV: The work of being watched. Lanham, MD: Rowman \& Littlefield.

Andrejevic, Mark. (2007). iSpy: Surveillance and power in the interactive era. Lawrence, KS: University Press of Kansas. 
Apple Inc. (2007a). 100 million iPods sold. URL: http://www.apple.com/pr/library/ 2007/04/09ipod.html [August 7, 2007].

Apple Inc. (2007b). Calamari [Television and Web ad]. URL: http://www.youtube.com/ watch? $\mathrm{v}=$ bhhbaaWBgnk [August 20, 2008].

Apple Inc. (2007c). Never been an iPod [Television and Web ad]. URL: http://www.youtube.com/watch?v=PQLTjiAfdLY [September 9, 2008].

Arnheim, Rudolf. (1988). The power of the center: A study of composition in the visual arts. Berkeley, CA: University of California Press.

Art Threat. (2008). Art Threat: Exploring the world of art and politics. URL: http://artthreat.net/about [August 22, 2008].

Barthes, Roland. (1972). Mythologies (Annette Lavers, Trans.). New York, NY: Hill \& Wang.

Barthes, Roland. (1978). Image, Music, Text (Stephen Heath, Trans.). New York, NY: Hill \& Wang.

BlogTO. (Toronto). (2008). URL: http://www.flickr.com/groups/blogto/pool/ [August 22, 2008].

Brinkley, Leslie. (2007, June 28). For sale? Spot in line for coveted iPhone. ABC News. URL: http://abclocal.go.com/kgo/story?section=news/business\&id=5433189 [May 29, 2008].

Burke, Kenneth. (1969). A rhetoric of motives. Berkeley, CA: University of California.

Carducci, Vince. (2006). Culture jamming: A sociological perspective. Journal of Consumer Culture, 6(1), 116-138.

Caron, Andre H., \& Caronia, Letizia. (2007). Moving cultures: Mobile communication in everyday life. Montréal, QC: McGill-Queen's University Press.

CNN. (2007, July 2). iPhone sales said to hit half-million. CNNMoney.com. URL: http://money.cnn.com/2007/07/02/technology/iphone_sales [May 29, 2008].

du Gay, Paul, Hall, Stuart, Janes, Linda, Mackay, Hugh, \& Negus, Keith. (1997). Doing cultural studies: The story of the Sony Walkman. London, UK: Sage Publications.

Elliot, Stuart. (2007, February 27). Academy awards ads routed Super Bowl's. International Herald Tribune. URL: http://www.iht.com/articles/2007/02/27/ business/adco.php [July 31, 2008].

Elmer-DeWitt, Philip. (2008). 30,000 Canadians petition for iPhone rate relief. Apple 2.0 Magazine blog. URL: http://apple20.blogs.fortune.cnn.com/2008/06/29/9000canadians-petition-steve-jobs-for-iphone-rate-relief [July 31, 2008].

Frazier, Mya. (2007). When a brand buster becomes a brand. Advertising Age, 78(47), 1-29.

Goldman, Robert, \& Papson, Stephen. (1998). Nike culture: The sign of the swoosh. London, UK: Sage.

Gow, Gordon A., \& Smith, Richard K. (2006). Mobile and wireless communications: An introduction. New York, NY: Open University Press.

Hallen, James. (2008). Open letter to Steve Jobs about the situation. URL: $\mathrm{http} / /$ www.ruinediphone.com/dearsteve.php [August 15, 2008].

Hawk, Byron, Rieder, David M., \& Oviedo, Ollie. (2008). Small tech: The culture of digital tools. Minneapolis, MN: University of Minnesota Press.

Hurtado, Joseph. (2007). Toronto-iPod city. URL: http://www.flickr.com/photos/trumpetca/508912611 [September 9, 2008]. 
Hutcheon, Linda. (2002). Postmodern afterthoughts. Wascana Review of Contemporary Poetry and Fiction, 37(1), 5-12.

iphonenoflash. (2007). iPhone parody no flash. URL: http://www.youtube.com/ watch? $\mathrm{v}=$ bjgXnMVMimg\&feature $=$ related [August 22, 2008].

Jenkins, Henry. (1992). Textual poachers: Television fans and participatory culture. New York, NY: Routledge.

Jenkins, Henry. (2006a). Convergence culture: Where old and new media collide. New York, NY: New York University Press.

Jenkins, Henry. (2006b). Fans, bloggers, and gamers: Media consumers in a digital age. New York, NY: New York University Press.

Jones, Dylan. (2005). iPod, therefore I am: Thinking inside the white box. New York, NY: Bloomsbury.

Kahney, Leander. (2005). The cult of iPod. San Francisco, CA: No Starch Press.

Kress, Gunther R., \& van Leeuwen, Theo. (2006). Reading images: The grammar of visual design (2nd ed.). New York, NY: Routledge.

Lasn, Kalle. (2000). Culture jam: How to reverse America's suicidal consumer binge-and why we must. New York, NY: Harper.

Lee, Ellen. (2007, June 27). The iLine begins. SFGate.com. URL: http://www.sfgate.com/ cgi-bin/blogs/sfgate/detail?blogid=19\&entry_id=18056 [May 29, 2008].

Mann, Steve, with Niedzviecki, Hal. (2001). Cyborg: Digital destiny and human possibility in the age of the wearable computer. Toronto, ON: Doubleday Canada.

Musgrove, Mike. (2007, January 10). Apple seeks to muscle into telecom with iPod phone. The Washington Post, p. D1.

Pedersen, Isabel. (2006). Mobility, human-centricity, and the design of wearable augmented reality interfaces. International Journal of the Humanities, 3(1), 143-154.

Rheingold, Howard. (2002). Smart mobs: The next social revolution. Cambridge, MA: Basic Books.

Sinnreich, Aram. (2007). Come together, right now: We know something's happening, but we don't know what it is. International Journal of Communication, 1, 44-47.

Soar, Michael. (2002). The First Things First manifesto and the politics of culture jamming: Towards a cultural economy of graphic designs and advertising. Cultural Studies, 16 (4), 570-592.

Stillar, Glenn. (1998). Analyzing everyday texts: Discourse, rhetoric and social perspectives. Thousand Oaks, CA: Sage.

Toronto 2007. (2007). URL: http://www.flickr.com/groups/toronto2007/pool [August 25, 2008].

Virilio, Paul. (2000). The information bomb. New York, NY: Verso. 